Jurnal Keperawatan Silampari

Volume 3, Nomor 2, Juni 2020

e-ISSN: 2581-1975

p-ISSN: 2597-7482

DOI: https://doi.org/10.31539/jks.v3i2.1115

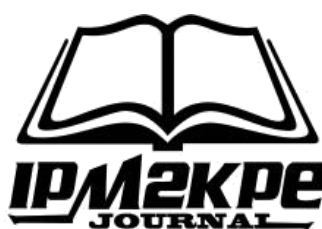

\title{
DUKUNGAN KELUARGA TERHADAP KEPATUHAN OBAT PADA PASIEN HUMAN IMMUNODEFICIENCY VIRUS DENGAN HARGA DIRI RENDAH
}

\author{
Buntar Handayani ${ }^{1}$, Sri Atun Wahyuning sih ${ }^{2}$ \\ Akademi Keperawatan Pelni Jakarta ${ }^{1,2}$ \\ handayanibuntar@gmail.com ${ }^{1}$
}

\begin{abstract}
ABSTRAK
Tujuan penelitian untuk mengetahui pengaruh dukungan keluarga dalam kepatuhan obat pada subjek human immunodeficiency virus dengan harga diri rendah di rumah sakit PELNI jakarta. Metode penelitian dalam penelitian ini pre eksperimental dengan rancangan one group pre test-post test design. Hasil penelitian menunjukan bahwa dukungan keluarga dapat memberikan dampak positif terhadap penurunan gangguan jiwa pada ODHA seperti kecemasan, stress, depresi dan harga diri rendah. Simpulan, hasil subjek I dan II yang mengalami harga diri rendah menyebabkan gangguan peran diri, ketidakmampuan, ketidakberdayaan, ideal diri yang negatif dan harga diri yang negatif
\end{abstract}

Kata Kunci: Dukungan Keluarga, Harga Diri Rendah Kepatuhan Obat, Human Immunodeficiency Virus

\section{ABSTRACT}

The purpose of the study was to determine the effect of family support in drug adherence on the subject of Human Immunodeficiency Virus with low self-esteem in the PELNI hospital in Jakarta. The research method in this study is Pre Experimental with One Group Pre-Test-Post Test Design. The results showed that family support could have a positive impact on reducing mental disorders in PLWHA, such as anxiety, stress, depression, and low self-esteem. Conclusions, the results of subjects I and II who experience low self-esteem cause disruption of self-role, disability, helplessness, negative self-ideal, and negative self-esteem.

Keywords: Family Support, Low Self-Esteem, Medication Adherence, Human Immunodeficiency Virus

\section{PENDAHULUAN}

Epidemi Human Immunodeficiency Virus/Acquired Immunodeficiency Syndromme (HIV/AIDS) semakin berkembang cepat dan merupakan salah satu tantangan terbesar dimasa kini sekalipun telah dilakukan berbagai upaya untuk mengendalikan dan menekan penularannya (Hastuti, 2017).

HIV terus menjadi masalah kesehatan publik global yang utama. Pada tahun 2018 diperkirakan 37,9 juta orang hidup dengan HIV (termasuk 1,7 juta anak), dengan prevalensi HIV global $0,8 \%$ di antara orang dewasa. Sekitar $21 \%$ dari orang yang sama ini tidak tahu bahwa mereka memiliki virus (UNAIDS, 2019). 
HIV terus menjadi isu kesehatan masyarakat global utama, yang telah menewaskan lebih dari 35 juta orang sejauh ini. Pada tahun 2016, satu juta orang meninggal akibat HIV secara global. Ada sekitar 36,7 juta orang yang hidup dengan HIV pada akhir tahun 2016 dengan 1,8 juta orang baru terinfeksi pada tahun 2016 secara global. HIV menargetkan sistem kekebalan tubuh dan melemahkan sistem pertahanan tubuh terhadap infeksi dan beberapa jenis kanker. Seiring virus menghancurkan dan merusak fungsi sel kekebalan tubuh, individu yang terinfeksi secara bertahap menjadi imunodefisiensi. Tahap paling lanjut dari infeksi HIV adalah Acquired Immuno Deficiency Syndrome (AIDS), yang dapat memakan waktu 2 sampai 15 tahun untuk berkembang tergantung pada individu. AIDS didefinisikan oleh perkembangan kanker, infeksi, atau manifestasi klinis berat lainnya (UNAIDS, 2018).

Pertengahan dekade keempat dari epidemi HIV (Human Immunodeficiency Virus), ada ruang untuk sedikit optimisme. Pada Hari AIDS Sedunia, 1 Desember 2015, UNAIDS (Joint United Nations Programme on HIV and AIDS) mengumumkan bahwa 15,8 juta orang sudah mengakses pengobatan HIV yang menyelamatkan jiwa. Dampaknya terlihat pada infeksi HIV baru yang berkurang 35\% sejak tahun 2000, serta mengurangi $42 \%$ kematian akibat AIDS yang memuncak di tahun 2004. Laporan UNAIDS ini meyakinkan kita bahwa kita berada di jalur cepat untuk mengakhiri AIDS pada tahun 2030 sebagai bagian dari tujuan pembangunan berkelanjutan yang membutuhkan investasi, komitmen dan inovasi (Parker et al., 2016).

Beberapa negara berpenghasilan tinggi termasuk Australia, Perancis, Inggris, dan Amerika Serikat, trend epidemi HIV secara keseluruhan menurun kecuali dalam komunitas LSL (laki-laki seks dengan laki-laki), dimana mereka telah berkembang di era ART yang digambarkan sebagai epidemi yang muncul kembali pada komunitas LSL. Di Amerika Serikat, infeksi HIV pada LSL diperkirakan akan meningkat pada sekitar $8 \%$ per tahun sejak tahun 2001. Dan di sebagian besar Afrika, Asia, dan Amerika Latin, tingkat tertinggi infeksi HIV dalam kelompok risiko berada LSL (Beyrer et al., 2017) . Kematian karena AIDS juga meningkat dan sekarang berdampak negatif terhadap harapan hidup. Dari Januari hingga Juni 2017, sekitar 14.631 kematian akibat AIDS tercatat, meningkat 13,5\% dari periode 6 bulan sebelumnya (Pokrovsky et al., 2017).

Pada tahun 2018, lebih dari setengah infeksi HIV baru secara global termasuk di antara populasi kunci yang terkena dampak dan pasangannya. Selain itu, mereka menyumbang lebih dari 95\% infeksi HIV baru di Eropa Timur dan Asia Tengah; 95\% infeksi HIV baru di Timur Tengah dan Afrika Utara; 88\% infeksi HIV baru di Eropa Barat dan Tengah dan Amerika Utara; 78\% dari infeksi HIV baru di Asia dan Pasifik; 65\% dari infeksi HIV baru di Amerika Latin; 64\% infeksi HIV baru di Afrika Barat dan Tengah; $47 \%$ infeksi HIV baru di Karibia dan 25\% infeksi HIV baru di Afrika timur dan selatan (UNAIDS, 2019).

Dukungan keluarga adalah kepatuhan terapi yang merupakan faktor penting pertama yang harus di dandani dalam perencanaan layanan terapi antiretroviral diantara orang yang terinfeksi HIV (Xu et al., 2017). Dukungan Keluarga sangat berperan penting terutama dalam memberikan dukungan kepada keluarga yang menderita HIV dan AIDS baik dari segi kepatuhan pengobatan, motivasi hidup.

Sejalan dengan penelitian yang dilakukan Afifah tahun 2019 Terdapat hubungan anatara dukungan keluarga dengan kepatuhan minum obat ARV pada pasien HIV/AIDS dengan nilai $\mathrm{p}$-value 0,000 ( $\mathrm{p}$-value $<0,05$ ) dan keeratan hubungan yaitu sangat kuat $(0,875)$ serta arah hubungannya positif (Afifah, 2019). 
Dukungan keluarga berperan penting dalam kepatuhan pasien ODHA minum obat. Penelitian yang dilakukan oleh Ngara, Wuan (2019) yang menunjukkan bahwa hasil uji Chi Square didapatkan nilai $p$ value $0,013<0,05$. Uji statistik bermakna ada hubungan yang signifikan antar variabel dukungan keluarga terhadap kepatuhan minum obat. Kepatuhan (adherence) merupakan faktor utama dalam mencapai keberhasilan pengobatan infeksi virus HIV. Kepatuhan (adherence) adalah minum obat sesuai dosis, tdak pernah lupa, tepat waktu, dan tdak pernah putus. Kepatuhan dalam meminum ARV merupakan faktor terpentng dalam menekan jumlah virus HIV dalam tubuh manusia. Penekanan jumlah virus yang lama dan stabil bertujuan agar sistem imun tubuh tetap terjaga tnggi. Dengan demikian, orang yang terinfeksi virus HIV akan mendapatkan kualitas hidup yang baik dan juga mencegah terjadinya kesakitan dan kematian (Karyadi, 2017).

Berdasasarkan studi pendahuluan di atas psikologis dan perilaku, bahwa perilaku kesehatan terutama tergantung pada keinginan untuk menghindari penyakit dan keyakinan bahwa tindakan tertentu akan mencegah atau meringankan penyakit. Model ini terdiri dari sejumlah dimensi, termasuk (a) kerentanan sakit yang dirasakan, yang merupakan keyakinan bahwa seseorang berisiko terkena penyakit atau, dalam kasus infeksi yang sebelumnya diderita, kepercayaan validitas diagnosis; (b) merasakan keparahan penyakit, yang meliputi perasaan tentang keseriusan tertular penyakit atau tidak mendapat pengobatan; (c) dirasakan manfaat dari pengobatan, yang berkaitan dengan keyakinan dalam efektivitas berbagai tindakan dalam mengurangi ancaman penyakit; dan (d) dirasakan hambatan untuk kepatuhan pengobatan, yang menggambarkan analisis manfaat biaya dimana individu menimbang efektivitas pengobatan terhadap konsekuensi negatif dari kepatuhan, seperti terganggunya aktivitas sehari-hari dan efek samping yang merugikan. Selain empat dimensi ini, HBM juga mendalilkan bahwa beragam demografis, psikososial, dan psikologis variabel dapat mempengaruhi persepsi individu dan dengan demikian secara tidak langsung mempengaruhi perilaku yang berhubungan dengan kesehatan.

Penelitian tentang dukungan keluarga terhadap kepatuhan obat pada pasien human immunodeficiency virus dengan harga diri rendah salah satu penelitian yang memiliki kelebihan dari pada penelitian lainya berfokus pada dukungan keluarga yang dikaitkan dengan harga diri rendah pasien dan asuhan keperawatan jiwa dimana hiv adalah salah satu penyakit menular yang semua orang bisa terkena kalau kita tidak berperilaku yang menyimpang, peran perawatan jiwa di sini bereperan aktif dalam membantu kepatuhan minum obat pasien dimana perawat jiwa selalu selalu memotivasi kepada pasien untuk meminum obat dan memberikan asuhan keperawatan jiwa demi kesembuhan pasien hinga memenuhi kebutuhan dasarnya. Dukungan keluarga sangat perlu dalam pengobatan pasien HIV sehinga psien tidak putus asa dalam pengobatan.

\section{METODE PENELITIAN}

Metode penelitian ini menggunakan metode penelitian pre eksperimental dengan rancangan one group pre test-post test design. Penelitian ini melibatkan 2 subjek yaitu orang dewasa yang memiliki penyakit human immunodeficiency virus yang memerlukan dukungan keluarga. Populasi yang digunakan dalam penelitian ini orang yang masih usia produktif terutama laki - laki berumur 25-40 tahun yang sudah dinyatakan sebagai ODHA dan sudah meminum obat 1 sampai dengan 4 bulan dan sempat putus obat di ruang rawat inap dukungan keluarga dalam kepatuhan obat pada subjek human immunodeficiency virus dengan harga diri rendah. Ciri dari penelitian ini adalah 
mengungkapkan hubungan sebab akibat dengan cara melibatkan subjek di observasi sebelum dilakukan intervensi, kemudian di observasi lagi setelah intervensi. Pengumpulan data menggunakan lembar kuesioner MMAS yang menunjukkan kepatuhan minum obat.

\section{HASIL PENELITIAN}

Tabel. 1

Pertemuan Intervensi Subjek 1

\begin{tabular}{|c|c|c|c|}
\hline NO Pertemuan & Tujuan & Respon & Kemajuan \\
\hline 1. Pertama & $\begin{array}{l}\text { Untuk meningkatkan } \\
\text { harga diri rendah }\end{array}$ & $\begin{array}{l}\text { Tampak diam, } \\
\text { bicara pelan merasa } \\
\text { malu tampak } \\
\text { murung kontak } \\
\text { mata kurang ketika } \\
\text { di ajak bicara } \\
\text { merasa cepat lelah } \\
\text { dan sulit tidur } \\
\text { keluarga juga } \\
\text { mengatakan Tn. A } \\
\text { lebigh banyak diam } \\
\text { setelah mengetahui } \\
\text { penyakitya keluhan } \\
\text { tersebut merupakan } \\
\text { pada aktifitas } \\
\text { kesehatan yang } \\
\text { lainya }\end{array}$ & $\begin{array}{l}\text { Subjek belum ada } \\
\text { kemajuan masih merasa } \\
\text { malu kontak mata masih } \\
\text { kurang keluarga belum } \\
\text { dapat melakukan } \\
\text { pendekatan secara optimal } \\
\text { untuk memberikan } \\
\text { dukungan kepada subjek }\end{array}$ \\
\hline 2. Dua & $\begin{array}{l}\text { Untuk meningkatkan } \\
\text { harga diri rendah dan } \\
\text { meningkatkan } \\
\text { dukungan keluarga }\end{array}$ & $\begin{array}{l}\text { Subjek mengatakan } \\
\text { tak bisa berperan } \\
\text { aktif dalam } \\
\text { keluarganya kelu } \\
\text { arga subjek merasa } \\
\text { selama ini kurang } \\
\text { memperhatikan } \\
\text { kondisi subjek. }\end{array}$ & $\begin{array}{l}\text { Subjek sudah mengalami } \\
\text { kemajuan sedikit, sudah } \\
\text { mampu menerima } \\
\text { keadaan saat ini, kontak } \\
\text { mata belum terarah, } \\
\text { komunikasi m,asih belum } \\
\text { terarah, keluarga sudah } \\
\text { mampu melakukan } \\
\text { pendekatan pada subjke } \\
\text { dan menanyakan apa yang } \\
\text { di alami subjek saat ini }\end{array}$ \\
\hline 3. Tiga & $\begin{array}{l}\text { Untuk meningkatkan } \\
\text { harga diri rendah } \\
\text { meningkat dukungan } \\
\text { keluarga dalam } \\
\text { kepatuhan obat }\end{array}$ & $\begin{array}{l}\text { Subyek dapat } \\
\text { berkomunikasi } \\
\text { dengan baik, kontak } \\
\text { mata sudah rerarah, } \\
\text { subjek dan keluarga } \\
\text { sudah tampak } \\
\text { saling, terbuka, } \\
\text { keluarga belum } \\
\text { mengetahui tentang } \\
\text { keptuhan minum } \\
\text { obat dan sudah } \\
\text { mengetahui setelah } \\
\text { di berikan penjelasa } \\
\text { oleh penelti }\end{array}$ & $\begin{array}{l}\text { Subjek masih ada } \\
\text { kemajuan sudah terbuka } \\
\text { kepada keluarga, merasa } \\
\text { dirinya sudah di } \\
\text { perhatikan dan keluarga } \\
\text { sudah mengetahui tentang } \\
\text { kepyuhan minum obat } \\
\text { dan sudah mencoba } \\
\text { memberikan dukungan } \\
\text { dalam keptuhan therapy } \\
\text { obat kepada subjek }\end{array}$ \\
\hline
\end{tabular}


Setelah dilakukan wawancara didapatkan hasil yang menunjukkan bahwa Subjek I Tn. A adalah karyawan swasta. Keluarga Tn, A sudah mengetahui penyakitnya tetapi keluarga belum memahami tentang terapi obat yang di berikan oleh dokter. Keluhan utama yang dirasakan yaitu merasa malu, merasa cepat lelah dan sulit tidur. Keluarga juga mengatakan bahwa Tn. A lebih banyak diam setelah mengetahui penyakitnya. Menurut keluarga penyakit yang diderita karena factor gaya hidup subjek Keluhan tersebut berdampak aktifitas keseharian klien.

Tabel. 2

Pertemuan Intervensi Subjek II

\begin{tabular}{|c|c|c|c|}
\hline NO Pertemuan & Tujuan & Respon & Kemajuan \\
\hline 1. Pertama & $\begin{array}{l}\text { Untuk meningkatkan } \\
\text { harga diri renda }\end{array}$ & $\begin{array}{l}\text { Tampak merasa } \\
\text { malu tampak } \\
\text { murung kontak } \\
\text { mata mudah beralih } \\
\text { ketika di ajak bicara } \\
\text { mengungkapkan } \\
\text { situasi yang di } \\
\text { alaminya } \\
\text { mengungkapkan } \\
\text { ketidakberdayaan } \\
\text { dan berselera, }\end{array}$ & $\begin{array}{l}\text { Subjek belum ada } \\
\text { kemajuan masih merasa } \\
\text { malu kontak mata masih } \\
\text { kurang keluarga belum } \\
\text { dapat melakukan } \\
\text { pendekatan secara optimal } \\
\text { untuk memberikan } \\
\text { dukungan kepada subjek }\end{array}$ \\
\hline 2. Dua & $\begin{array}{l}\text { Untuk meningkatkan } \\
\text { harga diri rendah dan } \\
\text { meningkatkan } \\
\text { dukungan keluarga }\end{array}$ & $\begin{array}{l}\text { Subjek mengatakan } \\
\text { tak bisa berperan } \\
\text { aktif dalam } \\
\text { keluarganya kelu } \\
\text { arga subjek merasa } \\
\text { selama ini kurang } \\
\text { memperhatikan } \\
\text { kondisi subjek. }\end{array}$ & $\begin{array}{l}\text { Subjek sudah mengalami } \\
\text { kemajuan sedikit, sudah } \\
\text { mampu menerima } \\
\text { keadaan saat ini, kontak } \\
\text { mata belum terarah, } \\
\text { komunikasi m,asih belum } \\
\text { terarah, keluarga sudah } \\
\text { mampu melakukan } \\
\text { pendekatan pada subjke } \\
\text { dan menanyakan apa yang } \\
\text { di alami subjek saat ini }\end{array}$ \\
\hline 3. Tiga & $\begin{array}{l}\text { Untuk meningkatkan } \\
\text { harga diri rendah } \\
\text { meningkat dukungan } \\
\text { keluarga dalam } \\
\text { kepatuhan obat }\end{array}$ & $\begin{array}{l}\text { Subyek dapat } \\
\text { berkomunikasi } \\
\text { dengan baik, kontak } \\
\text { mata sudah rerarah, } \\
\text { subjek dan keluarga } \\
\text { sudah tampak } \\
\text { saling, terbuka, } \\
\text { keluarga belum } \\
\text { mengetahui tentang } \\
\text { keptuhan minum } \\
\text { obat dan sudah } \\
\text { mengetahui setelah } \\
\text { di berikan } \\
\text { penjelasan oleh } \\
\text { penelti }\end{array}$ & $\begin{array}{l}\text { Subjek masih ada } \\
\text { kemajuan sudah terbuka } \\
\text { kepada keluarga, merasa } \\
\text { dirinya sudah di } \\
\text { perhatikan dan keluarga } \\
\text { sudah mengetahui tentang } \\
\text { kepyuhan minum obat } \\
\text { dan sudah mencoba } \\
\text { memberikan dukungan } \\
\text { dalam keptuhan therapy } \\
\text { obat kepada subjek }\end{array}$ \\
\hline
\end{tabular}

Setelah dilakukan wawancara didapatkan hasil yang menunjukkan bahwa Subjek II Tn. W adalah karyawan swasta. Keluarga Tn, W merasa sangat kaget dengan keadaan Tn. W karena hasil pemeriksaan CD 4 pada Tn. W sudah sangat rendah yaitu $8 \mathrm{~mm} 3$. Keluhan utama yang dirasakan oleh subjek adalah batuk berdahak sejak 7 hari yang 
lalu, demam serta berkeringat di malam hari. mengungkapkan tidak mampu menghadapi situasi yang di alami, mengungkapkan ketidakberdayaan, dan penurunan selera makan. Keluarga mengatakan bahwa subjek sudah pernah putus obat karena kurang pengawasan dari keluarga. Saat meminum obat CD 4 Tn. W sempat mencapai $800 \mathrm{~mm} 3$ dan pada saat di rawat Tn. W ditemukan juga penyakit lain yaitu tuberculosis (TB paru). Subjek tidak pernah menggunakan pengobatan alternative untuk mengobati penyakitnya. Subjek tidak pernah melakukan olahraga secara rutin. Subjek dan keluarga mengatakan penyakit yang di derita karena dulu subjek menggunakan narkotika.

\section{PEMBAHASAN}

Hasil penelitian yang di dapatkan Tn. A, berjenis kelamin laki-laki, berumur 29 tahun, bertempat tinggal di pringsewu, lampung, klien sudah menikah, klien bekerja sebagai karyawan swasta, suku bangsa lampung, agama islam, pendidikan terakhir S1. Subjek mereupakan anak tunggal, tinggal serumah dengan bapak dan istrinya. Subjek masuk dengan keluhan utama yaitu demam sejak 3 hari yang lalu, dilakukan pemeriksaan fisik TD 96/63 mmHg, N 75 x/menit, S 37,4 o C, tinggi badan $170 \mathrm{~cm}$, berat badan $68 \mathrm{~kg}$. subjek I tampak diam, bicara pelan, merasa malu, tampak murung, kontak mata kurang ketika di ajak bicara, merasa cepat lelah dan sulit tidur.

Keluarga kooperatif untuk dilakukan wawancara oleh penelitian sedangkan Tn. $\mathrm{W}$, berjenis kelamin laki-laki, berumur 39 tahun, bertempat tinggal di kemandoran 1, Jakarta Pusat. Klien belum berkeluarga, agama islam, suku bangsa jawa, pendidikan terakhir SMA, pekerjaan karyawan swasta. Subjek mereupakan anak ketiga dari tiga bersaudara, tinggal serumah dengan ibunya. Subjek masuk dengan keluhan utama yaitu batuk berdahak sejak 7 hari yang lalu, demam serta berkeringat di malam hari. dilakukan pemeriksaan fisik TD 110/80 mmHg, N 80 x/menit, S 37,4 o C, tinggi badan $175 \mathrm{~cm}$, berat badan $59 \mathrm{~kg}$. subjek I tampak diam, merasa malu, tampak murung, kontak mata mudah beralih ketika di ajak bicara, mengungkapkan tidak mampu menghadapi situasi yang di alami, mengungkapkan ketidakberdayaan, dan penurunan selera makan. Keluarga kooperatif untuk dilakukan wawancara oleh peneliti pada table di bawah ini.

Pada penelitian ini diambil 2 sample yang di sebut subjek I dan II karakteristik subyek penelitian tidak memiliki perbedaan dimana kedua subjek berjenis kelamin lakilaki dan mempunyai umur yang masih produktif dan dibuktikan oleh Pusdatin Kemenkes RI, 2016 yang menyatakan bahwa pada kelompok laki-laki. Untuk kelompok umur, infeksi HIV cenderung meningkat pada kelompok umur produktif yaitu kelompok umur 25-49 tahun sebanyak 10.974 jiwa dan pada kelompok perempuan sebesar 6.873 jiwa.

Sesudah dilakukan intervensi subjek I dan II keduanya sama sama mengalami penurunan harga diri rendah, pada subjek I mengalami penurunan harga diri rendah tetapi lambat, sebelum dilakukan intervensi klien mendapat scoring 29 melalui scrining tanda dan gejala harga diri rendah dapat di simpulkan subjek I mengalami harga diri rendah .karena subjek merasa sedih dan tampak lebih diam setelah mengetahui penyakitnya serta kurangnya keluarga dalam memperhatikan kondisi subjek, setelah di lakukan tindakan dilakukan scrining kembali di dapat kan hasil scoring menurun menjadi 2.

Hasil penelitian yang di lakukan fransiskus tahun 2019 gambaran kepatuhan minum obat antiretroviral (arv) pada orang dengan hiv aids di puskesmas wedomu kabupaten belu Nusa tenggara Timur jumlah virus yang lama dan stabil bertujuan agar system tubuh imun tetap terjaga. Dengan demikian, orang yang terinfeksi virus 
HIV akan mendapatkan kualitas hidup yang baik dan juga mencegah terjadinya kesakitan dan kematian. Tujuan dari penelitian ini adalah untuk mengidentifikasi kepatuhan minum obat antiretroviral (ARV) pada orang dengan HIV/AIDS sampel sebanyak 16 responden yang memenuhi kriteria inklusi Teknik pengambilan sampel dengan total sampling Hasil penelitian ditemukan 87,5 \% responden memiliki kepatuhan tinggi dalam mengkonsumsi obat ARV, dan 12,5\% memiliki kepatuhan yang rendah. Disarankan agar pemegang program HIV/AIDS di puskesmas melakukan pendampingan yang optimal agar semakin meningkatkan tingkat kepatuhan pasien dalam mengkonsumsi obat ARV. Kepada peneliti selanjutnya supaya melakukan penelitian serupa dengan teknik mengobservasi penderita dalam konsumsi ARV sejak awal t erapi, sambil follow up terhadap viral load dan CD4 (Tae et al., 2019).

Hasil Penelitian dilakukan Umah, Irawanto (2019) dari penelitian ini kepatuhan minum obat ARV pada pasien sebelum dilakukan intervensi termasuk kategori kepatuhan rendah dan sesudah dilakukan intervensi termasuk kategori kepatuhan sedang. Hasil uji statistik wilcoxon signed ranks test di dapatkan nilai $\hat{\mathrm{A}}=0,000$ ( $\hat{\mathrm{A}}<0,05)$, yang berarti ada pengaruh motivasi spiritual terhadap kepatuhan minum obat ARV pada pasien HIV/AIDS.

Dukungan keluarga suatu meningkatnya kepatuhan terapi yang merupakan faktor penting pertama yang harus di dandani dalam perencanaan layanan terapi antiretroviral diantara orang yang terinfeksi HIV (Xu et al., 2017). Dukungan Keluarga sangat berperan penting terutama dalam memberikan dukungan kepada keluarga yang menderita HIV dan AIDS baik dari segi kepatuhan pengobatan, motivasi hidup. Sejalan dengan penelitian yang dilakukan Afifah tahun 2019 terdapat hubungan anatara dukungan keluarga dengan kepatuhan minum obat ARV pada pasien HIV/AIDS dengan nilai $p$-value 0,000 (p-value $<0,05$ ) dan keeratan hubungan yaitu sangat kuat $(0,875)$ serta arah hubungannya positif (Afifah, 2019).

Dalam dukungan keluarga juga harus ada konseling mencakup informasi efek samping, resistensi serta manfaat pengobatan dan edukasi bagi keluarga ODHA. Hal ini ditujukan untuk pemantauan kepatuhan minum obat dan memberikan dorongan, motivasi dan sebagai pengingat dalam mengkonsumsi obat ARV dapat meningkatkan kepercayaan pasien terhadap terapi yang dijalani dan harus adanya keterbukaan antara ODHA dengan keluarga agar keluarga tetap mendukung untuk pengobatan antriretroviral. Selain dengan melakukan konseling dan edukasi, tenaga medis dan pemerintah harus bersinergi dalam menjaga keterjangkauan terapi ARV karena seringkali permasalahan ekonomi menjadi alasan ketidakpatuhan penderita dalam menjalani terapi mengingat terapi yang dilakukan seumur hidup penderita (Bachrun, 2017).

Keluarga merupakan sebuah sumber pertolongan praktis dan konkrit. Bila salah satu anggota keluarga yang sakit, secara nyata keluarga harus memberikan pertolongan, dalam hal ini penderita HIV/AIDS memerlukan pertolongan keluarga. Kepatuhan dalam pengobatan akan meningkat ketika pasien atau penderita mendapatkan bantuan dari keluarga seperti dukungan sosial yang berupa informasi, dukungan emosional, dukungan penghargaan dan dukungan fasilitas (Ngara, Wuan, 2019).

Hasil penelitian Bachrun (2017) Hubungan dukungan keluarga dengan kepatuhan minum obat antiretroviral pada orang dengan hiv/aids (odha) patuhan menentukan seberapa baik pengobatan antiretroviral (arv) dalam menekan jumlah viral load jika terapi yang dijalankan tidak serius maka virus akan menjadi resistensi. Dukungan keluarga atau orang terdekat karena keluarga merupakan orang terdekat yang 
mempunyai hubungan kekerabatan yang diharapkan mampu sebagai pendorong dan memotivasi odha dalam mengkonsumsi obat arv. Hasil penelitian keluarga yang mendukung odha di kds sehati sebesar 54\%, keluarga yang tidak mendukung sebesar $46 \%$, kepatuhan minum obat arv di kds sehati sebesar 48\%, ketidak patuhan minum arv sebesar 52\%. Sedangkan untuk analisis chi-square dukungan keluarga dengan kepatuhan minum obat arv pada orang dengan hiv/aids (odha) di kds sehati memperoleh nilai $\mathrm{p}$ value $=0,004$ dengan nilai $\alpha=0,05$, yang berarti ada hubungan dukungan keluarga dengan kepatuhan minum obat arv pada orang dengan hiv/aids (odha) di kds sehati.

Dukungan keluarga merupakan salah satu menjadi motivasi penderita HIV/AIDS selain dari program-program yang ditetapkan oleh rumah sakit dalam menjalani program pengobatan dan dukungan keluarga yang diberikan berupamperhatian dan memberikan penjelasan saran-saran yang dapat memotivasi pasien dalam menjalani program pengobatan HIV/AIDS. Sehingga dukungan keluarga berperan besar dalam hal kepatuhan minum obat ARV pada ODHA dalam menjalani pengobatan. Dengan adanya dukungan keluarga yang baik akan mempengaruhi positif pada kepatuhan minum obat ARV pada maka responden akan merasa keluarga selalu mendukung responden untuk menjalankan pengobatannya sehingga dapat mengurangi viral load pada ODHA tersebut berupa dukungan kasih sayang, informasi, material, nasehat dan motivasi dalam minum ARV secara teratur. Selain dukungan keluarga hal yang terpenting adalah sikap penderita sendiri untuk patuh dalam menjalani pengobatan ARV yang merupakan upaya dari peningkatan kualitas hidup ODHA (Bachrun, 2017).

Berbeda dengan penelitian yang dilakukan Nurihwani, Bujawati (2017) dari hasil penelitian dapat disimpulkan bahwa dukungan keluarga tidak mempempengaruhi tingkat kepatuhan pengobatan ARV, disebabkan ODHA tidak memberi tahu kepada keluarga tentang penyakitnya karena takut dikucilkan dan di telantarkan akibat stigma tentang penderita HIV dan AIDS dianggap telah melanggar norma-norma keluarga. Sehingga ODHA lebih terbuka kepada pendamping ODHA, sahabat sesama ODHA, dan petugas kesehatan. Dari hasil penelitian, disarankan kepada petugas kesehatan agar memberi tahu ODHA dampak jika tidak patuh dalam pengobatan ARV dan memberikan motivasi kepada ODHA, untuk memberi tahu keluarganya tentang penyakitnya.

\section{SIMPULAN}

Berdasarkan hasil penelitian mengenai analisis intervensi dukungan keluarga dalam kepatuhan obat pada subjek human immunodeficiency virus dengan harga diri rendah di Rumah Sakit PELNI Jakarta didapatkan hasil subjek I dan II yang mengalami harga diri rendah menyebabkan gangguan peran diri, ketidakmampuan, ketidakberdayaan, ideal diri yang negative dan harga diri yang negatif.

Hasil setelah diberikan intervensi pada kedua Subjek I dan II tersebut menunjukan adanya perubahan penurunan harga diri rendah serta memberikan pengaruh dampak yang positif bagi subjek dan keluarga yaitu adanya dukungan keluarga dalam kepatuhan obat dengan harga diri rendah.

\section{SARAN}

\section{Bagi Pengembangan Ilmu dan Teknologi Keperawatan}

Bagi perawat diharapkan dapat mensosialisasikan alternative baru ini, berupa pemberian dukungan keluarga dalam kepatuhan therapy obat pada subjek dengan human immunodeficiency virus dengan harga diri rendah. 


\section{Bagi Rumah Sakit Bagi Pihak Rumah Sakit}

Diharapkan dapat menjadikan bahan masukan agar memberikan asuhan keperawatan psikososial tentang intervensi dukungan keluarga dalam kepatuhan terapi obat pada subjek dengan human immunodeficiency virus (HIV/AIDS) dengan harga diri rendah.

\section{Bagi Institusi Pendidikan}

Diharapkan dapat menambah buku-buku penelitian, tentang harga diri rendah di perpustakaan untuk mendukung peneliti-peneliti berikutnya.

\section{Bagi Peneliti Selanjutnya}

Bagi peneliti selanjutnya diharapkan penelitian ini dapat digunakan sebagai data dan informasi dasar untuk penelitian selanjutnya dan diharapkan peneliti selanjutnya dapat dikembangkan.

\section{DAFTAR PUSTAKA}

Afifah, N. (2019). Hubungan Dukungan Keluarga dengan Kepatuhan Minum Obat Antiretroviral (ARV) pada Pasien Human Immunodeficiency Virus/Acquired Immune Deficiency Syndrome (Hiv/Aids) di Rumah Sakit Islam Sultan Agung Semarang. Universitas Islam Sultan Agung Semarang

Bachrun, E. (2017). Hubungan Dukungan Keluarga dengan Kepatuhan Minum Obat Antiretroviral pada Orang Dengan Hiv/Aids (Odha). Jurnal Elektronik, 7(1), 5761. https://doi.org/10.1017/CBO9781107415324.004

Beyrer, C., Wirtz, A. L., O’Hara, G., Léon, N., \& Kazatchkine, M. (2017). The Expanding Epidemic of HIV-1 in the Russian Federation. PLoS Medicine, 14(11), 6-11. https://doi.org/10.1371/journal.pmed.1002462

Hastuti, T. (2017). Hubungan Dukungan Keluarga terhadap Kepatuhan Minum Anti Retro Viral (ARV) pada Ibu Rumah Tangga dengan HIV AIDS di Rumah Sakit Umum Kabupaten Marauke. Universitas 'Aisyiyah Yogyakarta

Karyadi, T. (2017). Keberhasilan Pengobatan Antiretroviral (ARV). Jurnal Penyakit Dalam Indonesia, 4(1), 2-4

Ngara, V. A., \& Wuan, A. O. (2019). Hubungan antara Dukungan Keluarga dengan Kepatuhan Minum Obat ARV pada Penderita HIV/AIDS di LSM Perjuangan Tahun 2019. Politeknik Kesehatan Kemenkes Semarang

Nurihwani, N., \& Bujawati, E. (2017). Hubungan Dukungan Keluarga terhadap Kepatuhan Pengobatan Antiretroviral (ARV) pada Orang dengan HIV dan AIDS (ODHA) di Puskesmas Jungpandang Baru Tahun 2017. UIN Alaudin Makassar

Parker, R. G., Perez-Brumer, A., Garcia, J., Gavigan, K., Ramirez, A., Milnor, J., \& Terto, V. (2016). Prevention Literacy: Community-Based Advocacy for Access and Ownership of the HIV Prevention Toolkit. Journal of the International AIDS Society, 19(1). https://doi.org/10.7448/IAS.19.1.21092

Pokrovsky, V., Ladnaia, N., \& Pokrovskaya, A. (2017). HIV/AIDS is Reducing the Number of Russians and Their Life Expectancy. Demographic Review, 4(1), 6582. https://doi.org/10.17323/demreview.v4i5.8568

Tae, F., Riwoerohi, E. D., \& Berek, P. (2019). Gambaran Kepatuhan Minum Obat Antiretroviral (ARV) pada Orang dengan HIV AIDS di Puskesmas Wedomu Kabupaten Belu Nusa Tenggara Timur. Jurnal Sahabat Keperawatan, 1(2), 61-69 
Umah, K., \& Irawanto, D. (2019). Motivasi Spiritual Meningkatkan Kepatuhan Minum Obat ARV pada Pasien Hiv / Aids (Spiritual Motivation to Improve ARV Drug Compliance in Hiv / Aids Patients). Journal of Ners Community, 10(2), 251-263

UNAIDS. (2018). 2017 Global HIV Statistic. In Ending the AIDS Epidemic (pp. 1-6)

UNAIDS. (2019). Global HIV and AIDS statistics | AVERT. Averting HIV And Aids, 6-12. http://www.avert.org/professionals/hiv-around-world/global-statistics

Xu, J. F., Ming, Z. Q., Zhang, Y. Q., Wang, P. C., Jing, J., \& Cheng, F. (2017). Family Support, Discrimination, and Quality of Life Among Art-Treated Hivinfected Patients: A Two-Year Study in China. Infectious Diseases of Poverty, 6(1), 1-10. https://doi.org/10.1186/s40249-017-0364-5 